\title{
Effect of probiotics and some spices as feed additives on the performance and behaviour of the Nile tilapia, Oreochromis niloticus
}

\author{
Magdy A. Soltan ${ }^{1}$ and Said M. El-Laithy ${ }^{2}$ \\ 1- Department of Animal Production, Faculty of Agriculture, Benha University, Egypt \\ 2- Department of Hygiene, Animal Behavior and Management. Faculty of Veterinary \\ Medicine, Benha University, Egypt
}

\begin{abstract}
ABSTABCT
Drobiotic microbial feed supplements are gaining wide acceptance in livestock production, and may be applicable to aquaculture production systems. The present study was designed to investigate the effect of incorporation of probiotics (Bacillus subtilis and Biogen $®$ ), spices (garlic or fennel) and also a combination of B. subtilis with garlic or fennel in the diets of Nile tilapia, Oreochromis niloticus. A total of 420 Nile tilapia fry were divided into seven treatments (3 replicates for each treatment) and fed on the experimental diets for 90 days. The basal diet was fomulated to contain $30 \% \mathrm{CP}$ and $2700 \mathrm{Kcal} \mathrm{ME} \mathrm{kg}^{-1}$ and divided into 7 diets. The $1^{\text {st }}$ one as a control diet (D1). The other diets were supplied by the diffeent additives, $B$. subtilis (D2), 0.2\% Biogen ${ }^{\circledR}$ (D3), $1 \%$ garlic (D4), $1 \%$ fennel (D5), B. subtilis+1\% garlic (D6) and B. subtilis+ $1 \%$ fennel (D7).

Results of the present experiment indicated that, supplementation of the basal diets with probiotics B. subtilis or Biogen ${ }^{\circledR}$ and spices (garlic or fennel) significantly $(\mathrm{P}<0.01)$ improved survival rate of Nile tilapia. A combination of $B$. subtilis and garlic or fennel showed the best fish survival rate but did not significantly differ from those recorded for the diets supplemented with probiotic or spices alone.
\end{abstract}

Feed intake (FI), feed utilization and growth performance of Nile tilapia including final body weight (BW), final body length (BL), weight gain (WG), specific growth rate (SGR), feed conversion ratio (FCR) and protein efficiency ratio (PER), were significantly $(\mathrm{P}<0.01)$ higher in all treatments than the control diet. The combination of $B$. subtilis and fennel in tilapia diets showed the best feed utilization (FCR and PER) and the highest growth performance (BW, BL, WG, and SGR) compared to the other treatments.

The highest and optimum feeding behaviour among treatments was observed in fish fed on the diet D7, while the lowest feeding behaviour was recorded in fish fed on the control diet (D1). Moreover, the combination of B. subtilis with garlic or fennel improved the feeding behaviour than that observed in fish fed on the diet supplemented with $B$. subtilis alone. There was no significant difference in agonistic activities amongst fish fed on the different diets supplemented with probiotics or spices and the control diet.

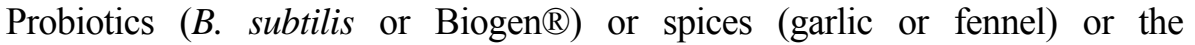
combinations of $B$. subtilis and garlic or fennel in the diets of Nile tilapia 
significantly $(\mathrm{P}<0.01)$ decreased hematocrite $(\mathrm{Ht})$ and reduced the levels of alanine aminotransferase (ALT) and aspartate aminotransferase (AST) while hemoglobin $(\mathrm{Hb})$ showed some variation (but not significant). Dry matter (DM), crude protein (CP) and ether extract (EE) of fish whole-body were significantly $(\mathrm{P}<0.05)$ affected by the different treatments compared to control fish group.

Key words: Nile tilapia, probiotics, Bacillus, Biogen ${ }^{\circledR}$, garlic, fennel, growth performance, feed utilization

\section{INTRODUCTION}

The demand for animal protein for human consumption is currently on the rise and is largely supplied from terrestrial farm animals. Aquaculture, however, is an increasingly important option in animal protein production. This activity requires high-quality feeds with a high protein content, which should contain not only the necessary nutrients but also complementary additives to keep organisms healthy and promote favourable growth. Some of the most utilized growthpromoting additives include hormones, antibiotics and some salts (Gongora, 1998; Klaenhammer and Kullen, 1999). Although these do promote growth, their improper use can result in adverse effects in the animal and the final consumer and can lead to resistance of pathogenic bacteria in case of antibiotics (El-Haroun et al., 2006). An alternative to the antibiotics is the use of beneficial bacteria (probiotic) to fight the pathogenic bacteria by competitive exclusion, which is an acceptable practice in animal husbandry (Sissons, 1989).

Schrezenmeir and de Vrese (2001) defined probiotics as a product containing viable, defined microorganisms in sufficient numbers, which alter the microflora in a compartment of the host and by that exert beneficial health effects in this host'. Probiotic protection can be due to mechanisms such as nutritional competition and/or production of antibacterial substances. Therefore, probiotics must be considered as potentially useful for the control of fish diseases (Irianto and Austin, 2002).

In aquaculture industry, several probiotic species were used, including Saccharomyces spp. (Surawicz et al., 1989), Lactobacillus acidopilus (Venkat et al. 2004), B. subtilis (Kumar et al., 2006, Ghosh et al. 2007; Keysami et al., 2007) and mixed cultures (Lessard and Brisson, 1987).

There has been increasing interest in the possible use of probiotics in aquaculture, including application in black tiger shrimp, Penaeus monodon (Rengpipat et al., 2000), salmonids Oncorhynchus nerka and rainbow trout, Salmo gairdneri (Irianto and Austin, 2002), white shrimp, Litopenaeus vannamei Boone (Venkat et al., 2004), Indian major carp, Labeo rohita Ham. (Kumar et al., 2006) and Penaeus japonicus and P. semisulcatus (Saleh, 2007).

Most probiotics are supplied as live supplements in the diet, which has the ability to survive the passage through the intestinal tract (Verschuere et al,. 2000). The direct nutritional benefits of probiotic bacteria include vitamin 
production, availability of minerals and trace elements and production of important digestive enzymes. Probiotics increases growth, improves efficiency, prevent intestinal disorders and stimulate pre-digestion of anti-nutritional factors present in the ingredients (Holzapfel et al., 1998).

Biogen ${ }^{\circledR}$ contains Bacillus licheniformis and $B$. subtilis. The advantage of these spore-forming bacteria is that they are able to survive the pelletization process. After passage through the stomach, they germinate in the intestine and use a large number of sugars (carbohydrates) for their growth and produce a range of relevant digestive enzymes, amylase, protease and lipase (El-Haroun et al., 2006).

Garlic (Allium sativum L.) is widely cultivated in Egypt and used as flavoring agent, a common feed and popular remedy. Because the thyroxin like activity of garlic, it is suggested that it has growth stimulating effect. Garlic stimulated growth by increasing the inflow of glucose into tissues and thyroid like activity (El-Nawawy, 1991). Sulfur compounds in garlic are considered as active antimicrobial agents and improve immunity and therefore stimulate growth (El-Afify, 1997) and have a mode of action similar to antibiotics (Ibrahim et al., 2004).

The present study was designed to investigate the effect of some probiotics

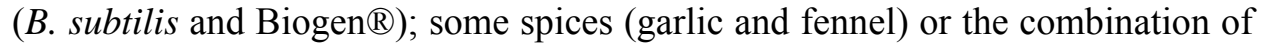
B. subtilis and each of garlic or fennel on viability, growth performance, feed utilization, liver function, feeding and aggressive behaviour and proximate composition of $O$. niloticus.

\section{MATERIALS AND METHODS}

Nile tilapia fry were obtained from The World Fish Center at Abbassa, Sharkya Governorate, Egypt and acclimated to laboratory conditions in 1700-L fibreglass tanks. The feeding trial was performed at the Fish Nutrition Lab (Faculty of Agriculture, Benha University, Egypt).

\section{Bacteial mixture preparation:}

B. subtilis strain was obtained in powdered form $\left(7 \times 10^{9}\right.$ cell per gram) from National Organization for Drug Control and Research, Cairo, Egypt. A bacterial mixture was prepared by mixing $10 \mathrm{mg}$ of $B$. subtilis powder with $990 \mathrm{mg}$ of wheat flour to give approximately $7 \times 10^{7}$ cell per gram.

\section{Diets and feeding regime:}

The basal diet was fomulated to contain $30 \% \mathrm{CP}$ and $2700 \mathrm{Kcal} \mathrm{ME} \mathrm{kg}^{-1}$ and divided into 7 diets. The $1^{\text {st }}$ one as a control diet while the other diets were supplied by the diffeent additives as shown in Table (1). In preparing the diets, dry ingredients were first ground to a small particle size and mixed thoroughly with added water to obtain a $30 \%$ moisture level. Diets were passed through a mincer with diameter of $2 \mathrm{~mm}$ and were sun-dried for 3 days. 


\section{Culture conditions:}

At the beginning of the experiment, 21 glass aquaria $(100 \times 50 \times 40 \mathrm{~cm})$ were supplied with freshwater $\left(180 \mathrm{~L}\right.$ for each) at a rate of $1 \mathrm{~L} \mathrm{~min}^{-1}$ with supplemental aeration and each aquarium was stocked by 20 fish (weight ranged from 2.60 to $2.65 \mathrm{~g}$ ). Fish were fed the diets at a daily rate of $10 \%$ (during the $1^{\text {st }}$ month), then reduced to $7 \%\left(2^{\text {nd }}\right.$ month $)$ and $4 \%\left(3^{\text {rd }}\right.$ month $)$ of total biomass. Fish were fed 6 days/week (twice daily at 9.00 am and $3.00 \mathrm{pm}$ ). The amount of feed was biweekly adjusted according to the changes in body weight throughout the experimental period (90 days).

Table (1): Composition of the basal diet used in the experiment.

\begin{tabular}{|c|c|c|c|c|c|c|c|}
\hline \multirow{2}{*}{ Ingredients } & \multicolumn{7}{|c|}{ Diets } \\
\hline & D1 & D2 & D3 & D4 & D5 & D6 & D7 \\
\hline Fish meal $(72 \% \mathrm{CP})$ & 16 & 16 & 16 & 16 & 16 & 16 & 16 \\
\hline Soybean meal $(44 \% \mathrm{CP})$ & 35 & 35 & 35 & 35 & 35 & 35 & 35 \\
\hline Yellow corn & 32 & 32 & 32 & 32 & 32 & 32 & 32 \\
\hline Wheat bran & 10 & 9 & 9.8 & 9 & 9 & 8 & 8 \\
\hline Vegetable oil & 4 & 4 & 4 & 4 & 4 & 4 & 4 \\
\hline Vit. \& Min. Mixture $^{1}$ & 3 & 3 & 3 & 3 & 3 & 3 & 3 \\
\hline $\begin{array}{l}\text { B. subtilis }\left(7 \times 10^{7} \text { cell } \mathrm{g}^{-}\right. \\
\left.{ }^{1}\right)\end{array}$ & - & 1 & - & - & - & 1 & 1 \\
\hline Biogen $\AA$ & - & - & 0.2 & - & - & - & - \\
\hline Garlic & - & - & - & 1 & - & 1 & - \\
\hline Fennel & - & - & - & - & 1 & - & 1 \\
\hline Sum & 100 & 100 & 100 & 100 & 100 & 100 & 100 \\
\hline \multicolumn{8}{|c|}{ Proximate analysis (determined on dr. matter basis) } \\
\hline Dry matter (DM) & 97.12 & 96.68 & 97.00 & 97.00 & 98.32 & 97.65 & 97.98 \\
\hline Crude protein $(\mathrm{CP})$ & 29.76 & 30.67 & 29.91 & 29.58 & 29.45 & 29.95 & 29.88 \\
\hline Ether extract (EE) & 6.47 & 7.05 & 7.32 & 7.76 & 6.67 & 7.00 & 7.16 \\
\hline Crude fiber $(\mathrm{CF})$ & 8.45 & 7.98 & 8.04 & 8.45 & 8.44 & 7.95 & 8.34 \\
\hline Ash & 9.00 & 7.66 & 7.25 & 8.13 & 9.11 & 7.87 & 8.11 \\
\hline $\mathrm{NFE}^{2}$ & 46.32 & 46.64 & 47.50 & 46.08 & 46.33 & 47.20 & 46.51 \\
\hline $\mathrm{ME}^{3}$ (Kcal/kg diet) & 2710 & 2760 & 2770 & 2785 & 2708 & 2730 & 2740 \\
\hline $\mathrm{P} / \mathrm{E} \mathrm{ratio}^{4}$ & 109.82 & 111.12 & 107.98 & 106.21 & 108.75 & 109.71 & 109.05 \\
\hline
\end{tabular}

1- Vitamin \& mineral mixture/kg premix : Vitamin $\mathrm{D}_{3}, 0.8$ million IU; A, 4.8 million IU; E, 4 g; K, 0.8 g; B1, 0.4 g; Riboflavin, 1.6 g; B6, 0.6 g, B12, 4 mg; Pantothenic acid, 4 g; Nicotinic acid, $8 \mathrm{~g}$; Folic acid, $0.4 \mathrm{~g}$ Biotin, $20 \mathrm{mg}$, Mn, $22 \mathrm{~g}$; Zn, $22 \mathrm{~g}$; Fe, $12 \mathrm{~g}$; Cu, 4 g; I, 0.4 g, Selenium, $0.4 \mathrm{~g}$ and $\mathrm{Co}, 4.8 \mathrm{mg}$.

2- Nitrogen free extract $(\mathrm{NFE})=100-(\mathrm{CP}+\mathrm{EE}+\mathrm{CF}+\mathrm{Ash})$

3-Metabolizable energy was calculated from ingredients based on NRC (1993) values for tilapia.

4- Protein to energy ratio in $\mathrm{mg}$ protein/kcal ME.

\section{Growth and feed utilization parameters:}

Growth performance and feed utilization parameters were determined according to Cho and Kaushik (1985) as follows:

Specific growth rate $(\mathrm{SGR})=[(\mathrm{LnW} 2-\mathrm{LnW} 1) / \mathrm{t}] \times 100$ Where: $\mathrm{Ln}=$ the natural $\log , \mathrm{W} 1=$ initial fish weight; $\mathrm{W} 2=$ the final fish weight in "grams" and $\mathrm{t}=$ period in days. 
Feed conversion ratio $(\mathrm{FCR})=$ feed intake $(\mathrm{g}) /$ wet weight gain $(\mathrm{g})$,Protein efficiency ratio $(\mathrm{PER})=$ weight gain $(\mathrm{g}) /$ protein intake $(\mathrm{g})$, Water quality: Parameters of water quality were determined according to the methods of APHA (1992). Ammonia and nitrite were measured at weekly intervals while water temperatures were recorded daily in each tank using a mercury thermometer suspended at 30-cm water depth. Also, dissolved oxygen was measured daily by oxygen meter and $\mathrm{pH}$ by $\mathrm{pH}$ meter.

\section{Behavioural observations:}

Behavioural observations were performed as follows: each treatment group was observed two times daily 15 minutes/time (5 minutes/aquarium) for 3 days/week at circularly predetermined time from 8 am to 5 pm (Fraser and Broom, 1990) for recording the feeding and aggressive behaviour. Any fish showed scraping feed on the water surface with opened mouth or fed on feed particles suspended at water column and on particles at the bottom of the aquarium was recorded to show feeding behaviour (Lovell, 1989) while any fish showed chasing toward other fish with opened mouth or biting other fish was recorded to show aggressive behaviour (Turner et al., 1988).

\section{Blood samples and liver functions:}

Blood samples were obtained from fish at the end of experimental period. Five fish per tank were randomly chosen and anaesthetized by ethylene glycol mono-phenol ether. Blood samples were collected from the caudal vein using heparinized 27-gauge needles and tuberculin syringes. Hematocrite ( $\mathrm{Ht})$ was determined using the micro-Ht method described by Brown (1988). Hemoglobin $(\mathrm{Hb})$ was determined using the total $\mathrm{Hb}$ kit (Sigma Diagnostics, Sigma, St Louis, MO. USA) which is standardized procedure using the cyanomethemoglobin method. Liver was removed, homogenized and assigned for determination of Aspartate transaminase (AST) and Alanine transaminase (ALT) according to Reitman and Frankel (1957).

\section{Chemical analysis:}

At termination of the experiment, three fish were randomly sampled from each tank and subjected to the chemical analysis of whole fish body. Chemical analysis of fish, diets and feces were determined according to the methods of AOAC (1990).

\section{Statistical analysis:}

The statistical analysis of data was carried out by applying the computer program, SAS (1996) by adopting the model: $Y_{i j}=\mu+\alpha_{i}+e_{i j}$ Where, $Y_{i j}=$ the observation on the $j^{\text {th }}$ fish eaten the $i^{\text {th }}$ diet; $\mu=$ overall mean, $\alpha_{i}=$ the effect of $i^{\text {th }}$ diet and $\mathrm{e}_{\mathrm{ij}}=$ random error. 


\section{Water quality:}

\section{RESULTS AND DISCUSSION}

During the whole experimental period, water temperature ranged from 26.45 to $29.33^{\circ} \mathrm{C}$, dissolved oxygen fom 4.16 to $6.67 \mathrm{mg} \mathrm{L}^{-1}, \mathrm{pH}$ from 7.60 to 7.90 and total ammonia from 0.11 to $0.14 \mathrm{mg} \mathrm{L}^{-1}$. There were no significant $(\mathrm{P}<0.05)$ differences in water quality parameters among treatments during the whole experimental period indicating that, the experimental diets had no detrimental effects on the surrounding water quality of experimental fish.

\section{Survival rate:}

As described in Table (2), survial rate for fish fed on the control diet was found to be $90 \%$. Supplementation of the control diet with B. subtilis, $0.2 \%$ Biogen ${ }^{\circledR}$, garlic or fennel significantly increased survival rates to $95.00,96.67$, 95.00 and $95.00 \%$, respecively. The combinations of B. subtilis with garlic or fennel also increased survival rate to $98.33 \%$. No significant differences $(\mathrm{P}>0.05)$ were observed among fish fed on garlic or fennel in survival. At the same time, incorporation of bacteria with garlic or fennel in the diets increased survival rate to $98.3 \%$ but did not significantly different from those recorded for fish fed the diets supplemented by garlic or fennel alone. El-Dakar and Goher (2004) used B. subtilis in micro-binding diets for Penaeus japonicus post-larvae. They found that the level of survival in response to bacterial challenge was high in shrimp fed the diet containing $B$. subtilis, while survival rate declined in the control shrimp fed the basal diet.

Superiority of B. subtilis in survival, growth and health status due to its effect as biocontrol or bacterial antagonism effect and production of antimicrobial agents such as antibiotic, antimicrobial peptide substances. Moreover, stimulation of the immune system using probiotic strains has been reported by Rengpipat et al. (2000). Several mechanisms have been suggested as modes of action for probiotic bacteria. The competitive exclusion mechanism, based on the substitution of pathogen by the beneficial population, has been considered to be important by many authors (Moriarty, 1998; Gatesoupe, 1999; Li and Galtin, 2004).

In the present study, supplementation of the basal diet by Biogen ${ }^{\circledR}$ resulted in higher survival rate than fish fed the control diet. Mehrim (2001) reported that addition of $0.3 \%$ Biogen ${ }^{\circledR}$ to the diet increased the survival rate of tilapia compared with the control diet (without Biogen ${ }^{\circledR}$ ). El-Barbary (2002) showed that survival rate of Nile tilapia was increased as Biogen ${ }^{\circledR}$ level increased from 0 to $0.4 \%$. The positive effect of Biogen ${ }^{\circledR}$ may be due to its spices (garlic and ginger) and the probiotic effects which serve as antitoxic, antibacterial and antifungal agents, which may lead to improve the survival rate. $B$. subtilis may play a vital role to control the pathogen. Ghosh et al. (2007) indicated that incorporation of pobiotics (B. subtilis) in fish diets significantly increased survival and decreased fry mortality. 


\section{Feed intake and feed utilization:}

Results of Table (2) indicated that, incorporation of probiotics (B. subtilis or Biogen ${ }^{\circ}$ ), spices (garlic or fennel) and the combination of $B$. subtilis with garlic or fennel significantly $(\mathrm{P}<0.01)$ improved feed intake $(\mathrm{FI}), \mathrm{FCR}$ and PER. The highest FI and the best FCR were obtained for fish fed the diet (D7) supplied by a mixture of $B$. subtilis and fennel and the worst FI, FCR and PER were obtained in fish fed the control diet (D1).

In practical terms, this means that supplementation of fish diets with probiotics or spices optimized protein use for the growth which can decrease the amount of feed necessary for fish growth, which could result in reducing production costs. Ringo and Gatesoupe (1998) showed a similar improvement in the biological value of the diets supplemented with probiotics.

Probiotic diet including $B$. subtilis or Biogen ${ }^{\circledR}$ and spices in the present study showed better feed intake and feed utilization compared to control diet. $B$. subtilis may serve in this case as a co-feeding of inert feed and may help to maximize the diets efficiency through stimulating digestive tract. Co-feeding not only stimulates the ingestion of feed particles, but also promotes digestion and assimilation of diets by fish (Koven et al. 1998). Biogen ${ }^{\circledR}$ compounds (garlic, ginger, $B$. subtilis and digestive enzymes) increased palatability of the diets containing Biogen $\AA$ through its attractive fragrant.

From a nutritional point of view and in agreement with the data of Shelby et al. (2006), the present results revealed that the use of the probiotic Biogen $\AA$ as a feed additive for Nile tilapia is recommended to stimulate productive growth performance and nutrient utilization (FCR and PER).

The superiority of some medicinal plants/spices in enhancing growth parameters can be attributed to 1) increasing palatability and maximize feed intake (Sakr, 2003); 2) enhancing activities of pancreatic lipase, chymotrypsin and amylase (Abou-Zeid, 1998), 3) improving protein and energy digestibility (Sakr, 2003); 4) increasing fish vitality (Abd El-Maksoud et al., 2002); 5) increasing fish immunity through its effects on the liver function (Ozbek et al., 2003) and 6) reducing the feed waste that causing improvement of aquatic culture environment for fish (El-Dakar et al., $2004 \mathrm{a}$ and b). About third of feed introduced to aquatic cultured animals is wasted into the water (Axler et al., 1996) causing adverse effect on water quality. Reduction of the feed waste is very important especially in culture systems depending on the reuse of rearing water. In this context, incorporation of some natural plants may cause a reduction of uneaten feed by aquatic cultured animals (Sakr, 2003). 
Table (2): Survival rate (SR), feed intake (FI), feed conversion ratio (FCR) and protein efficiency ratio (PER) as affected by incorporation of probiotics and spices in the diets of Nile tilapia.

\begin{tabular}{lcccc}
\hline \multirow{2}{*}{ Experimental diets } & \multirow{2}{*}{ Survival rate \% } & FI (g/fish) & \multicolumn{2}{c}{ Feed utilization } \\
\cline { 4 - 5 } & & & FCR & PER \\
\hline D1(Control) & $90.00 \mathrm{~b}$ & $36.22 \mathrm{c}$ & $1.70 \mathrm{a}$ & $1.98 \mathrm{c}$ \\
D2 B. subtilis & $95.00 \mathrm{a}$ & $44.65 \mathrm{~b}$ & $1.52 \mathrm{~b}$ & $2.22 \mathrm{c}$ \\
D3 (0.2\% Biogen $®)$ & $96.67 \mathrm{a}$ & $50.97 \mathrm{a}$ & $1.35 \mathrm{c}$ & $2.48 \mathrm{~b}$ \\
D4 (1\% garlic) & $95.00 \mathrm{a}$ & $37.45 \mathrm{c}$ & $1.33 \mathrm{c}$ & $2.53 \mathrm{~b}$ \\
D5 (1\% fennel) & $95.00 \mathrm{a}$ & $38.83 \mathrm{c}$ & $1.16 \mathrm{~d}$ & $2.92 \mathrm{a}$ \\
D6 (B. subtilis $+1 \%$ garlic) & $98.33 \mathrm{a}$ & $41.89 \mathrm{~b}$ & $1.34 \mathrm{c}$ & $2.50 \mathrm{~b}$ \\
D7 (1\% B. subtilis $+1 \%$ fennel) & $98.33 \mathrm{a}$ & $50.72 \mathrm{a}$ & $1.19 \mathrm{~d}$ & $2.83 \mathrm{a}$ \\
\pm Standard error & \pm 0.55 & \pm 1.48 & \pm 0.06 & \pm 0.03 \\
Probability & 0.0043 & 0.0035 & 0.0021 & 0.0021 \\
\hline
\end{tabular}

Means followed by the different letters in each column for each trait are significantly different $(\mathrm{P}<0.05)$.

\section{Growth performance:}

As described in Table (3), supplementation of control diet with each of $B$. subtilis, Biogen $\AA$, garlic, fennle or the combinations of $B$. subtilis with each of garlic or fennel significantly $(\mathrm{P}<0.001)$ improved growth parameters $(\mathrm{BW}, \mathrm{BL}, \mathrm{WG}$ and SGR). The best growth parameters (BW, BL, WG and SGR) were recorded for fish fed the diet D7 in which the basal diet was supllied by a combination of B. subtilis and fennel and the worst one was recorded for fish fed the control diet.

Results of the present study indicated that fennel was better than garlic when used as feed additives alone or in a combination with B. subtilis in Nile tilapia diets. In agreement with the obtained results, El-Dakar et al. (2004 b) found that fennel seed meal used in tilapia diets significantly improved SGR than those fed the control diet.

The obtained results may be due to the effect of probiotics that inhibit the colonization of potential pathogens in the digestive tract by antibiosis or by competition for nutrients and space, and alteration of the microbial metabolism. It also improves the nutrition by detoxifying the potentially harmful compounds in feeds, by producing vitamins such as biotin and vitamin B12 (Hoshino et al., 1997), and by stimulating host immunity (Gibson et al., 1997). Another possible explanation for increased growth performance with added probiotic is the improvement in digestibility, which may in turn explain the better growth and feed efficiency observed with the supplemented diets. Otherwise, probiotics influence digestive processes by enhancing the population of beneficial microorganisms, microbial enzyme activity; improving the intestinal microbial balance, consequently improving the digestibility and absorption of food and feed utilization (Bomba et al., 2002).

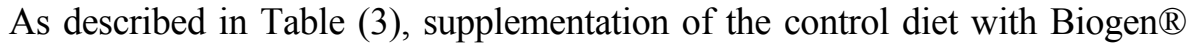
improved all growth parameters (BW, BL, WG and SGR). The main ingredients of Biogen ${ }^{\circledR}$ are allicien (the product of garlic), ginsieng, B. subtilis, high units of hydrolytic enzymes (amylolytic, lipolytic, proteolytic and cell separating enzymes). 
The high unit hydrolytic enzyme group of Biogen $\AA$ my make the starch, fat, protein of feeds to be entirely dissociated and absorbed in gastrointestinal tracts of the poultry and domestic animals.

Biogen ${ }^{\circledR}$ can enhance the metabolism of fish body cells, raise the efficiency of feed utilization and balance the secretion of various secretary glands. Moreover, it increases the vitality of cells by supplying oxygen to whole body and improves the immune responses (Diab el al. 2002), helps to excrete heavy metals, inhibits aflatoxin and stimulates the normal endocrine system. Elam (2004) found that BW and WG of Mugil and tilapia fish significantly increased when the diets were supplemented by $0.2 \%$ Biogen $\AA$. Saleh (2007) showed that there was a significant increase in body weight of shrimp as Biogen ${ }^{\circ}$ level increased till $0.1-0.2$ then it decreased at level of 0.3 .

Table (3): Parameters of growth performance, as affected by incorporation of probiotics and spices in the diets of Nile tilapia.

\begin{tabular}{|c|c|c|c|c|c|c|c|}
\hline \multirow[b]{2}{*}{ Experimental diets } & \multirow[t]{2}{*}{ No. } & \multicolumn{2}{|c|}{ BW (G) } & \multicolumn{2}{|c|}{$\mathrm{BL}(\mathrm{cm})$} & \multirow{2}{*}{$\begin{array}{c}\text { WG } \\
\text { (g/fish) }\end{array}$} & \multirow[t]{2}{*}{ SGR } \\
\hline & & Initial & Final & Initial & Final & & \\
\hline D1(Control) & 60 & 2.61 & $23.98 \mathrm{c}$ & 5.41 & $10.74 \mathrm{~d}$ & $21.37 \mathrm{~d}$ & $2.46 \mathrm{e}$ \\
\hline D2 B. subtilis & 60 & 2.60 & $32.10 \mathrm{~b}$ & 5.12 & $12.27 \mathrm{~b}$ & $29.50 \mathrm{c}$ & $2.79 \mathrm{c}$ \\
\hline D3 (0.2\% Biogen $\AA)$ & 60 & 2.62 & $40.49 \mathrm{ab}$ & 5.40 & $13.87 \mathrm{a}$ & $37.87 \mathrm{ab}$ & $3.04 \mathrm{ab}$ \\
\hline D4 (1\% garlic) & 60 & 2.59 & $30.79 \mathrm{~b}$ & 5.44 & $12.15 \mathrm{~b}$ & $28.20 \mathrm{c}$ & $2.75 \mathrm{~d}$ \\
\hline D5 ( $1 \%$ fennel) & 60 & 2.61 & $33.80 \mathrm{~b}$ & 5.30 & $12.60 \mathrm{~b}$ & $31.19 \mathrm{~b}$ & $2.85 \mathrm{c}$ \\
\hline D6 ( $1 \%$ B. subtilis $+1 \%$ garlic) & 60 & 2.60 & $35.99 \mathrm{~b}$ & 5.34 & $12.92 \mathrm{~b}$ & $33.39 \mathrm{~b}$ & $2.92 \mathrm{~b}$ \\
\hline D7 ( $1 \%$ B. subtilis $+1 \%$ fennel $)$ & 60 & 2.63 & $45.43 \mathrm{a}$ & 5.28 & $13.93 \mathrm{a}$ & $42.80 \mathrm{a}$ & $3.17 \mathrm{a}$ \\
\hline \pm Standard error & & +0.11 & \pm 0.99 & 0.04 & \pm 1.67 & \pm 0.92 & \pm 0.02 \\
\hline Probability & & 0.8472 & 0.0008 & 0.9002 & 0.0005 & 0.0010 & 0.0010 \\
\hline
\end{tabular}

Means followed by the different letters in each column for each trait are significantly different $(\mathrm{P}<0.05)$.

\section{Feeding and aggressive behavioure}

Results of Table (4) indicate that the highest and optimum feeding behaviour (98.33\%) among all treatments was observed in fish fed the diet D7, while the lowest feeding behaviour (76.67\%) was recorded by fish fed the control diet (D1). Also, the combination of B. subtilis with garlic or fennel improved the feeding behaviour than that observed in fish fed the diet supplemented with $B$. subtilis alone. The obtained results may be due to the increasing palatability of diets (Sakr, 2003) and increasing the vitality of fish fed the diets containing probiotics and spices (Abd ElMaksoud et al., 2002).

The results of Table (4) also indicate that, there was no significant difference in agonistic activities amongst fish fed the different diets supplemented with probiotics or spices and the control diet. The reduction in the percent of agonistic activities between fish groups fed the different diets may be due to that all fish groups in the present study did not reach 
the age of sexual maturity and most cichlid fish of both sexes do not hold feeding territories and are non aggressive until the establishment of breeding territories (Schwank, 1987). Turner et al. (1988) reported that, for Tilapia mariae reared in the laboratory, non-breeding fish in large groups are generally non-aggressive and non-territorial.

Table (4): Feeding and aggressive behaviour of Nile tilapia as affected by incorporation of probiotics and spices in the diets.

\begin{tabular}{lcc}
\hline Experimental diets & Feeding behaviour \% & Aggressive behaviour \% \\
\hline D1(Control) & $76.67 \mathrm{c}$ & 3.33 \\
D2 (B. subtilis) & $88.33 \mathrm{~b}$ & 3.33 \\
D3 (0.2\% Biogen $®)$ & $96.67 \mathrm{a}$ & 1.67 \\
D4 (1\% garlic) & $88.33 \mathrm{~b}$ & 1.67 \\
D5 (1\% fennel) & $88.33 \mathrm{~b}$ & 3.33 \\
D6 (1\% B. subtilis + 1\% garlic) & $96.67 \mathrm{a}$ & 1.67 \\
D7 (1\% B. subtilis +1\% fennel) & $98.33 \mathrm{a}$ & 3.33 \\
\pm Standard error & \pm 1.78 & 0.32 \\
Probability & 0.0007 & 1.0904 \\
\hline
\end{tabular}

Means followed by the different letters in each column for each trait are significantly different $(\mathrm{P}<0.05)$.

\section{Blood parameters and liver functions:}

Results of Table (5) indicate that, supplementation of the basal diet with feed additives (probiotics or spices) significantly $(\mathrm{P}<0.01)$ decreased hematocrite $(\mathrm{Ht})$ and hemoglobin $(\mathrm{Hb})$ level showed some variation (but not significant). Fish fed the control diet showed the highest levels of $\mathrm{Hb}$ and $\mathrm{Ht}$ while fish fed the diet supplemenmted with garlic showed the lowest ones followed by those fed the diet supplemented by Bioen ${ }^{\circledR}$. Similar results were obtained by Kumar et al. (2006). They found that, serum $\mathrm{Hb}$ level of Indian major carp Labeo rohita (Ham) did not significantly differ from as B. subtilis supplemented to the diets.

Compared to control serum level, transferase enzymes (ALT and AST) were significantly decreased when the other diets were supplemented with all treatments specially those fed the diet enriched by garlic or with Bigoen ${ }^{\circledR}$. These results indicate that probiotics or spices removed the toxic factors of the diets and therefore improved liver function. Shalaby et al. (2003) found that activity of liver enzymes (ALT and AST) were markedly decreased in tilapia fed diets containing licorice roots than those fed the control diet. El-Dakar et al. (2004b) showed significant lower $(\mathrm{P}<0.05)$ ALT and AST activities with fish fed fennel seed meal in diets.

Garlic inhibits the fatty acids synthesis and other lipid components in liver and reduces the level of fat accumulation in liver, which leads to a decrease in liver weight (Ibrahim et al., 2004). Garlic contains a variety of organosulphur compounds, amino acids, vitamins and minerals (Block, 1985). Sulphur 
compounds of garlic are responsible for inhibition of cholesterol synthesis (Liu and Yeh, 2000). Garlic is reported to have hypoglycemic (Al-Salahy, 2002). The possible mechanism in hypoglycemic effects of garlic was due to enhancement of insulin level in blood either by stimulating secretion of insulin cells or converting proinsulin to insulin.

Table (5): Blood parameters and liver functions of Nile tilapia as affected by incorporation of probiotics and spices in the diets.

\begin{tabular}{lcccc}
\hline Experimental diets & $\mathrm{Hb}\left(\mathrm{g} \mathrm{dL}^{-1}\right)$ & $\mathrm{Ht}(\%)$ & ALT & AST \\
\hline D1(Control) & 7.19 & $27.48 \mathrm{a}$ & $45.77 \mathrm{a}$ & $48.24 \mathrm{a}$ \\
D2 (B. subtilis) & 7.35 & $26.22 \mathrm{a}$ & $41.33 \mathrm{~b}$ & $43.82 \mathrm{~b}$ \\
D3 (0.2\% Biogen $®)$ & 6.47 & $23.29 \mathrm{~b}$ & $42.17 \mathrm{~b}$ & $42.36 \mathrm{~b}$ \\
D4 (1\% garlic) & 6.89 & $20.00 \mathrm{c}$ & $42.02 \mathrm{~b}$ & $42.22 \mathrm{~b}$ \\
D5 (1\% fennel) & 7.93 & $26.03 \mathrm{a}$ & $45.00 \mathrm{a}$ & $43.57 \mathrm{~b}$ \\
D6 (1\% B. subtilis +1\% garlic) & 7.43 & $25.32 \mathrm{a}$ & $43.24 \mathrm{a}$ & $44.54 \mathrm{~b}$ \\
D7 (1\% B. subtilis +1\% fennel) & 7.78 & $26.62 \mathrm{a}$ & $44.91 \mathrm{a}$ & $40.98 \mathrm{~b}$ \\
\pm Standard error & \pm 0.83 & \pm 1.32 & \pm 1.56 & \pm 1.25 \\
Probability & 0.0629 & 0.0043 & 0.0020 & 0.0031 \\
\hline
\end{tabular}

Means followed by the different letters in each column for each trait are significantly different $(\mathrm{P}<0.05)$.

\section{Proximate analysis of fish whole-body:}

Concerning proximate whole-body composition, results of Table (6) indicate that, DM, CP and EE contents of Nile tilapia were significantly $(\mathrm{P}<0.05)$ influenced by the different treatments, while ash content showed some variations (but not significant) among the different teatments. This is expected as fish in all treatments did not grow essentially at the same rate. Barros et al. (2000) and Yildirim et al. (2003) reported that body fat content is closely related to weight gain and inversely related to body moisture content and this agreed with the obtained results of the present study.

Fish fed the diet D7 showed the highest DM and EE and the lowest CP contents of the whole body, while the opposite trend was recorded for fish fed the control diet which showed the lowest DM, EE, ash and the highest CP of the whole body.

\section{Conclusion:}

Based on the obtained results, it is recommended to supplement tilapia diets with probiotics or spices and apply different combinations of probiotics and spices as natural feed additives. Further research is still needed to detect the mode of action of probiotics on digestibility, immune response and stress resistance. Also, it is important to define the probiotic levels administered to fish to avoid over-dosing and under-dosing with resultant lower efficacy and unnecessary costs. 
Table (6): Proximate analysis of fish whole-body (based on dry matter) of Nile tilapia as affected by incorporation of probiotics and spices in the diets.

\begin{tabular}{llccc}
\hline \multicolumn{1}{c}{ Experimental diets } & DM & CP & EE & Ash \\
\hline D1(Control) & $24.12 \mathrm{c}$ & $68.89 \mathrm{a}$ & $13.12 \mathrm{c}$ & 15.84 \\
D2 (B. subtilis) & $25.23 \mathrm{bc}$ & $66.72 \mathrm{ab}$ & $14.26 \mathrm{~b}$ & 17.12 \\
D3 (0.2 Biogen $\left.{ }^{\circledR}\right)$ & $25.54 \mathrm{~b}$ & $66.82 \mathrm{ab}$ & $15.00 \mathrm{~b}$ & 16.18 \\
D4 (1\% garlic) & $25.87 \mathrm{bc}$ & $67.20 \mathrm{a}$ & $14.74 \mathrm{~b}$ & 16.44 \\
D5 (1\% fennel) & $26.46 \mathrm{~b}$ & $66.76 \mathrm{ab}$ & $15.43 \mathrm{~b}$ & 16.23 \\
D6 (1\% B. subtilis $+1 \%$ garlic) & $26.67 \mathrm{~b}$ & $66.34 \mathrm{ab}$ & $16.89 \mathrm{ab}$ & 15.34 \\
D7 (1\% B. subtilis $+1 \%$ fennel) & $29.11 \mathrm{a}$ & $65.16 \mathrm{~b}$ & $17.23 \mathrm{a}$ & 16.24 \\
\pm Standard error & \pm 1.88 & \pm 1.85 & \pm 0.86 & \pm 0.97 \\
Probability & 0.0541 & 0.0331 & 0.0253 & 0.0611 \\
\hline
\end{tabular}

Means followed by the different letters in each column for each trait are significantly different $(\mathrm{P}<0.05)$.

\section{REFERENCES}

Abd El-Maksoud, A.M.; Aboul-Fotoh, G.E.; Allam, S.M. and Abou Zied, R.M. (2002). The response of Nile tilapia to animal protein free diets supplemented with some free amino acids and some medicinal plants. Proc. $1^{\text {st }}$ Conf. Aquacult., 13-15 December, El-Arish, Egypt. Aquacult. Soc. pp.233-260.

Abou-Zeid, R. M. (1998). Evaluation of some medicinal plants as a feed additive in diets of Nile tilapia, Oreochromis niloticus. M.Sc Thesis. Faculty of agriculture, El-Fayoum, Cairo University, Egypt.

Al-Salahy, M. B. (2002). Some physiological studies on the effect of onion and garlic juices on the fish, Clarias lazera. Fish Physiology and Biochemistry, 27:142-142.

AOAC (Association of Official Analytical Chemists) (1990). Official Methods of Analysis. $15^{\text {th }}$ edn. AOAC, Arlington, VA, USA.

APHA, (1992). Standard methods for the examination of water and waste water. American Public Health Association. Washington. Dc.

Axler, R. C.; Larcen, C.; Tekkanen, C.; McDonald, M. and Yokom, S. (1996). Water quality issues associated with aquaculture. A case study in mine pit takes . Water Environment Research, 68: 995-997.

Barros, M. M.; Lim, C.; Evans, J. J. and Klesius, P. H. (2000). Effects of iron supplementation to cottonseed meal diets on growth performance of channel catfish, Ictalurus punctatus. J. Appl. Aquacult., 10:65-86. 
Block, E. (1985). The chemistry of garlic and onions: a number of curious sulfur compounds underlie the odor of garlic and the crying brought on by slicing an onion. Sci. Am., 252:114-119

Bomba A.; Nemcoa R.; Gancarc-Ova S.; Herich R.; Guba P. and Mudron-Ova D. (2002). Improvement of the probiotic effect of micro-organisms by their combination with maltodextrins, fructo-oligosaccharides and polyunsaturated fatty acids. British Journal of Nutrition, 88(Suppl.1):95-99.

Brown, B. A. (1988). Routine hematology procedures. In: Hematology: Principle and Procedures (ed, by B. A. Brown). pp. 7-122. Leo and Febiger, Philadelphia, PA. USA.

Cho, C. Y. and Kaushik, S. J. (1985). Effect of protein intake on metabolizable and net energy values of fish diets. In: Nutrition and Feeding in Fish (ed. by C.B. Cowey, A.M. Mackie \& J.G. Bell ), pp. 95- 117. Academic Press, London, UK

Diab, A. S.; El-Nagar, G. O. and Abd El-Hady, Y. M. (2002). Evaluation of Nigella sativa L. (Black seed (baraka), Allium sativum (garlic) \& Biogen ${ }^{\circledR}$ as a feed additives on growth performance and immunostimulants of Oreochromis niloticus fingerlings. SCVMJ., 5 (2):745-753.

El-Afify, S. F. (1997). Nutritional studies on onion and garlic supplement to poultry feed. Ph.D. Thesis, Fac. Agric. Ain-Shams University.

Elam, T. A. (2004). Effect of Biogen $\AA$ and Bio-Mos on growth performance, production and some biochemical changes in Oreochromis niloticus and Mugil cephalus. The First Sci. Conf. Fac. Vet. Med., Moshtohor, Benha-Ras Sedr, Sep. 1- 4, 2004.

El-Barbary, M. I. (2002). Studies on aflatoxin in Fish. Ph.D. Thesis, Faculty of Agricultural Sciences, Al-Mansourah University, Egypt.

EL-Haroun, E. R.; Goda, A. M. and Chowdhury, M. A. (2006). Effect of dietary probiotic Biogen ${ }^{\circledR}$ supplementation as a growth promoter on growth performance and feed utilization of Nile tilapia, Oreochromis niloticus (L.). Aquaculture Research, 37:147-1480.

El-Dakar, A.Y. and Goher, T.M. (2004). Using of Bacillus subtilis in microparticulate diets for producing biosecure of Peneaus japonicus postlarvae. Agric. Sci. Mansoura Univ., 29 (12):6855-6873. 
El-Dakar, A.Y.; Hassanien G. D.; Gad, S.S. and Sakr, S. E. (2004a). Use of medical and aromatic plants in fish diets: I. Effect of dried marjoram leaves on performance of hybrid tilapia Oreochromis niloticus $\times$ O. aureus, fingerlings. J. Egypt. Acad. Soc. Environ. Develop. (B. Aquaculture), 5 (1): 67-83.

El-Dakar, A. Y.; Hassanien G. D. I.; Gad, S. S. and Sakr, S. E. (2004b). Use of medical and aromatic plants in fish diets: 2. Effect of dried basil leaves on performance of hybrid tilapia Oreochromis niloticus $\times$ O. aureus, Fingerlings. 3 rd Inter. Conf. on Anim. Production and Health in semi-Arid Areas, Suez Canal Univ.pp. 265-277.

El-Nawawy, . H. (1991). Some of non conventional ingredients in broiler ration. M.Sc. Thesis, Fac. Agric. Ain-Shams University.

Fraser, A. F. and Broom, D. M. (1990). Farm animals Behaviour and Welfare. $3^{\text {rd }}$ Ed. Bailliere Tindall.

Gatesoupe, F.J. (1999). The use of probiotics in aquaculture. Aquacult., 180: 147165.

Ghosh, S.; Sinha, A. and Sahu, C. (2007). Effect of probiotic on reproductive performance in female livebearing ornamental fish. Aquaculture Research, 38:518-526.

Gibson G. R.; Saavendra J. M.; MacFarlane S. and MacFarlane G. T. (1997). Probiotics and intestinal infections. In: Probiotics 2, Application and Practical Aspects (ed. by R. Fuller), pp.10-32 Chapman \& Hall, London.

Gongora C. M. (1998). Mecanismos de resistencia bacteriana ante la medicina actual. McGraw-Hill, Barcelona,456 pp.

Holzapfel, W. H.; Haberer, P.; Snel, J.; Schillinger, U. and Huisin't Veld, J. (1998). Overview of gut flora and probiotics. International Journal of Food Microbiology, 41:85-101.

Hoshino T.; Ishizaki K.; Sakamoto T.; Kumeta H.;Yumoto I.; Matsuyama H. and Ohgiya S. (1997). Isolation of a Pseudomonas species from fish intestine that produces a protease active at low temperature. Letters in Applied Microbiology, 25:70-72.

Ibrahim, I. A.; Elam, T. A.; Mohamed, F. F.; Awadalla, S. A. and Yousif, Y. I. (2004). Effect of onion and/or garlic as feed additives on growth performance 
and immunity in broiler muscovy ducks. The First Sci. Conf. Fac. Vet. Med., Moshtohor, Benha-Ras Sedr, Sep. pp.1- 4, 2004.

Irianto, A. and Austin, B. (2002). Use of probiotics to control furunculosis in rainbow trout, Oncorhynchus mykiss (Walbaum). Journal of Fish Diseases, 25:333-342.

Keysami, M. A.; Saad, C. R.; Sijam, K.; Daud, H. M. and Alimon, A. R. (2007): Effect of Bacillus subtilis on growth development and survival of larvae Macrobrachium rosenbergii (de Man). Aquaculture Nutrition, 13:131-136.

Klaenhammer, T. D. and Kullen, M. J. (1999). Selection and design of probiotics. International Journal of Food Microbiology, 50: 45-57.

Koven, W.M.; Kissil, G.W. and Tandler, A. (1998). Lipid and $\omega_{3}$ requirement of Sparus aurata larvae during starvation and feeding. Aquaculture, 79: 185-191.

Kumar, R.; Mukherjee, S. C.; Prasad, K. P. and Pal, A. K. (2006). Evaluation of Bacillus subtilis as a probiotic to Indian major carp Labeo rohita (Ham.). Aquacult. Research, 37:1215-1221.

Lessard, M. and Brisson, G. J. (1987). Effect of a Lactobacillus fermentation product on growth, immune response and fecal enzyme activity in weaned pigs. Can. J. Anim. Sci., 67:509-516.

Li, P. and Galtin III, D.M. (2004). Dietary brewers yeast and the prebiotic Grobiotick $^{\mathrm{TM}} \mathrm{AE}$ influence growth performance, immune responses and resistance of hybrid striped bass (Morone chrysops $\times$ M. saxatilis) to Streptococcus iniae infection. Aquaculture, 231: 445-456.

Lovell, T. (1989). Nutrition and feeding of fish. $3^{\text {rd }}$ Ed. Van Nostrand Reinhold, New York, pp 163-164.

Lui, M. and Yeha, Y. Y. (2000). Inhibition of cholesterol biosynthesis by organo sulfur compound derived from garlic. Lipids, 35:147-203

Mehrim, A.I. M. (2001). Effect of some chemical pollutants on growth performance and feed and nutrient utilization of tilapia. M.Sc. Thesis, Faculty of Agriculture, Saba Basha University Alexandria

Moriarty, D.J. (1998). Control of luminous Vibrio specis in penaeid aquaculture ponds. Aquacult., 164: 351-358. 
NRC (1993). National research Council. Nutrient Requirements of Fish. National Academy Press, Washington, DC, 114 pp.

Ozbek H.; Ugras S.; Dulger H.; Bayram I.; Tuncer I.; Ozturk G. and Ozturk A. (2003). Hepatoprotective effect of Foeniculum vulgare essential oil. Altern. Ther, Health Med., 9 (4):58-61.

Reitman, S. and Frankel, F. (1957). A colorimetric method for determination of oxaloacetic transaminase and serum glutamic pyruvic transaminase. A. J. Clin. Path, 28:56-60.

Rengpipat S.; Rukpratanporn S.; Piyatiratitivorakul S. and Menasveta P. (2000). Immunity enhancement in black tiger shrimp (Penaeus monodon) by a probiont bacterium (Bacillus S11). Aquaculture, 191:271-288.

Ringo, E. and Gatesoupe F. J. (1998). Lactic acid bacteria in fish: a review. Aquaculture, 160:177-203.

SAS (1996). SAS Procedure Guide "version 6.12 Ed”. SAS Institute Inc., Cary, $\mathrm{NC}$, USA.

Sakr, S.E. (2003). Studies on the feeding attractants for fish. M.Sc Thesis. Fac. of Environ. Agric. Sci., El-Arish, Suez Canal Univ., Egypt.

Saleh, T. S. A. (2007). Use of microparticulated diets in marine larval feeding. M.Sc Thesis. Fac. of Environ. Agric. Sci., El-Arish, Suez Canal Univ., Egypt.

Schrezenmeir, J. and de Vrese, M. (2001). Probiotics, prebiotics and synbiotics: approaching a definition. American Journal of Clinical Nutrition, 73:361-364.

Schwank, E. (1987). Reproductive behaviour of a monogamous cichlid Fish Tilapia mariae. Ph.D. Thesis University of Stockholm, Sweeden.

Shalaby, S.M.; Abd Elmonem, A. I. and El-Dakar, A. Y. (2003). Enhancement of growth performance, feed and nutrient utilization of Nile tilapia, Oreochromis niloticus, using of licorice roots (Erksous) as a feed attractive. J. Egypt. Acad. Soc. Environ. Develop. (B-Aquaculture), 4 (2):119-142.

Shelby, R. A.; Lim, C. E.; Aksoy, M. and Delaney, M. A. (2006). Effects of probiotic feed supplements on disease resistance and immune response of young Nile tilapia (Oreochromis niloticus). Journal of Applied Aquaculture, 18:23-34. 
Sissons, J. W. (1989). Potential of probiotic organisms to prevent diarrhoea and promote digestion in farm animals. Journal of Food Science and Agricult., 49:1-13.

Surawicz, C. M.; Elme, G. W. and Speelman, P. (1989). Prevention of antibioticassociated diarrhea by Saccharomyces boulardii: a prospective study. Gastroenterology, 84:1285-1287.

Turner, G. F.; Phiri, L. M. and Cawthrw, S. (1988). Partner attack inhibition in the sexual monomorphic Biparental chichlid Tilapia mariae, Behaviour, pp 1-9.

Venkat, H. K.; Sahu, N. and Jain, K. K. (2004). Effect of feeding Lactobacillusbased probiotics on the gut microflora, growth and survival of postlarvae of Macrobrachium rosenbergii (de Man). Aquaculture Research, 35:501-507.

Verschuere, L.; Rombaut, G.; Sorgeloos, P. and Verstraete, W. (2000). Probiotic Bacteria as Biological Control Agents in Aquaculture. Microbiology and Molecular Biology Review, 64:655-671.

Yildirim, M.; Lim, C.; Wan, P. and Klesius, P. H. (2003). Growth performance and immune response of channel catfish (Ictalurus punctatus) fed diets containing graded levels of gossypol-acetic acid. Aquaculture, 219:751-768. 